\title{
RELEVANSI NILAI INFORMASI AKUNTANSI DENGAN MODEL VALUASI OHLSON
}

\author{
Randy Kuswanto ${ }^{1}$ (randy_kuswanto.yahoo.com) \\ Alumni Fakultas Ekonomi Universitas Maritim Raja Ali Haji \\ Prima Aprilyani Rambe ${ }^{2}$ (aprilyaniprima@yahoo.com) \\ Fakultas Ekonomi Universitas Maritim Raja Ali Haji \\ Sri Ruwanti ${ }^{3}$ (sriruwanti@yahoo.com) \\ Fakultas Ekonomi Universitas Maritim Raja Ali Haji
}

\begin{abstract}
ABSTRAK
Penelitian ini bertujuan menguji pengaruh nilai buku ekuitas dan nilai laba per saham terhadap nilai perusahaan dengan model valuasi Ohlson (1995) dan informasi kondisi laba/rugi perusahaan terhadap relevansi nilai yang terjadi. Populasi dalam penelitian ini adalah seluruh perusahaan manufaktur yang terdaftar di Bursa Efek Indonesia pada tahun 2013-2014.Teknik sampling yang digunakan dalam penelitian ini adalah purposive sampling. Hasil penelitian ini menunjukkan bahwa variabel nilai buku per lembar saham dan nilai laba per saham secara parsial dan simultan mempengaruhi nilai perusahaan. Hasil ini dapat menjadi bukti empiris terhadap model valuasi Ohlson (1995). Selain itu, kondisi laba/rugi perusahaan juga mempengaruhi hubungan relevansi nilai. Pada kondisi laba/rugi positif relevansi nilai buku per saham menjadi lebih rendah. Sedangkan pada kondisi laba/rugi positif, relevansi nilai laba per saham menjadi lebih tinggi. Penelitian ini menggunakan variabel afiliasi grup bisnis, struktur kepemilikan saham dan ukuran perusahaan sebagai varabel kontrol.
\end{abstract}

Kata Kunci : Relevansi Nilai, Laba Per Saham, Nilai Buku Ekuitas Per Saham, Afiliasi Grup Bisnis, Struktur Kepemilikan Saham, Ukuran Perusahaan, Kondisi Laba/Rugi Perusahaan

\section{PENDAHULUAN}

Informasi akuntansi yang digunakan dalam pengujian pasar efisien merupakan informasi yang memiliki relevansi. Informasi akuntansi bisa diperoleh salah satunya dengan melakukan analisis fundamental terhadap laporan keuangan suatu perusahaan. Analisis fundamental merupakan analisis yang dilakukan oleh investor guna mendapat data yang diperlukan untuk pengambilan keputusan investasi. Analisis ini mempraktekkan harga saham di masa mendatang dengan mengestimasi nilai faktor-faktor fundamental yang mempengaruhi harga saham di masa yang akan datang dan menerapkan hubungan variabel-variabel tersebut (Martalena dan Malinda, 2011).

Konsep relevansi nilai mengemukakan bahwa informasi yang berasal dari laporan keuangan perusahaan harus memberikan nilai manfaat bagi para penggunanya dalam pengambilan keputusan (Puspitaningtyas, 2012). Dalam penelitian ini, nilai buku ekuitas dan laba perusahaan dinilai memiliki relevansi terhadap pembentukan harga saham (Adhani \& Subroto, 2013; Cahyonowati \& Ratmono, 2012; Gumanti \& Utami, 2004; Lailia, 2010; Martalena \& Malinda, 2011). Namun, metode pengujian relevansi nilai di negara berkembang 
seperti di Indonesia yang menghubungkan variabel informasi akuntansi dengan harga atau return saham di pasar modal yang tidak efisien akan menimbulkan bias pada koefisien relevansi nilai yang dihasilkan (Adhani dan Subroto, 2013). Hal ini membuat asumsi pasar modal efisien yang dikemukakan oleh Fama harus diterapkan.

Banyak penelitian empiris yang telah dilakukan mengenai topik relevansi nilai. Relevansi nilai antara informasi akuntansi dengan nilai pasar saham telah banyak dikemukakan di berbagai penelitian. Hal ini menguatkan bahwa informasi akuntansi yang terdapat dalam laporan keuangan memiliki hubungan statistik dengan nilai perusahaan yang dapat tercermin dari harga dan return saham(Adhani \& Subroto, 2013; Cahyonowati \& Ratmono, 2012; Gumanti \& Utami,2004; Lailia, 2010; Martalena \& Malinda, 2011; Nurhasanah, 2013; Hand, 2005; Keener, 2003; Brief \& Zarowin, 2010).

Berdasarkan penelitian yang telah dilakukan sebelumnya, maka penelitian ini bertujuan untuk menguji relevansi nilai informasi keuangan menurut model valuasi Ohlson (1995) pada perusahaan yang terdaftar dalam Bursa Efek Indonesia pada periode 2013-2014. Penelitian ini mengacu pada penelitian yang dilakukan oleh Subekti (2010). Perbedaan penelitian ini dengan penelitian terdahulu adalah penelitian ini mengikutsertakan jenis kepemilikan perusahaan dan struktur afiliasi perusahaan sebagai variabel kontrol dalam model regresi. Selain itu ditambah dua variabel kontrol baru yaitu ukuran perusahaan dan kondisi laba perusahaan dalam model regresi. Variabel kondisi laba perusahaan berguna untuk mengelompokkan perusahaan yang dalam kondisi laba/rugi negatif dan laba/rugi positif.

Penelitian ini paling tidak dapat memberikan kontribusi dalam dua hal yaitu, penelitian ini dapat memberikan bukti keterkaitan informasi akuntansi yang ada dalam laporan keuangan perusahaan terhadap harga saham. Kedua adalah penelitian ini dapat mengemukakan pengaruh kondisi laba perusahaan dalam hubungannya terhadap model yang mempengaruhi terhadap pembentukan nilai perusahaan.

\section{LANDASAN TORI}

\section{Relevansi Nilai Informasi Akuntansi}

Relevansi nilai informasi akuntansi merupakan perwujudan kualitas informasi akuntansi. Dalam konsep relevansi nilai, kualitas informasi akuntansi dikatakan baik jika terdapat hubungan kuat antara nilai perusahaan yang tercermin dengan harga saham dengan nilai-nilai akuntansi berupa nilai buku ekuitas dan laba suatu perusahaan (Puspitaningtyas, 2012). Relevansi nilai bermanfaat untuk menginvestigasi hubungan empiris antara nilai akuntansi di dalam laporan keuangan dengan nilai pasar harga saham perusahaan untuk menilai pengaruh data akuntansi tersebut dalam penilaian fundametal perusahaan.

Kunci utama dalam mengukur pasar yang efisien secara informasi adalah hubungan antara harga sekuritas dan informasi. Investor memerlukan informasi yang relevan dalam melakukan analisis fundamental. Harga saham dipengaruhi persepsi investor terkait kinerja perusahaan dimasa mendatang. Harga saham akan meningkat jika investor memprediksi kinerja suatu perusahaan akan meningkat. Sebaliknya harga saham akan turun jika investor memprediksi kinerja perusahaan akan menurun. Informasi yang terkandung dalam laporan keuangan merupakan salah satu faktor yang mempengaruhi persepsi investor dalam mengukur kualitas informasi yang digunakan dalam mendeteksi harga saham (Puspitaningtyas, 2012). 


\section{Teori Surplus Bersih}

Teori surplus bersih merupakan teori yang dicetuskan oleh James A Ohlson pada tahun 1995. Teori ini didasari pada konsep nilai dalam teori ekonomi neoklasik. Teori surplus bersih menjelaskan hubungan antara data akuntansi dan nilai perusahaan dengan mengasumsikan investor memiliki keyakinan dan preferensi yang homogen. Asumsi yang kedua mengatakan bahwa terdapat hubungan surplus bersih antara ekuitas dan laba (Kusumo \& Subekti, 2013). Teori ini menunjukkan bahwa nilai pasar perusahaan dapat diekspresikan dalam variabel laporan laba rugi dan neraca. Hal ini menunjukkan bahwa nilai perusahaan dipengaruhi oleh variabel akuntansi yang fundamental dan konsisten dengan perspektif pengukuran. Teori surplus bersih menekankan pada kegunaan dari informasi laporan keuangan saat ini untuk memprediksi earning dimasa depan (Ohlson, 1995).

\section{Model Valuasi Ohlson}

Model Ohlson (1995) adalah yang paling dikenal dari model relevansi nilai yang bertujuan untuk merumuskan hubungan antara nilai-nilai akuntansi dan nilai perusahaan. Model Ohlson sendiri merupakan model dalam akuntansi yang termasuk model pengukuran yaitu menyangkut nilai-nilai fundamental informasi keuangan. Model Ohlson adalah kerangka teoretis yang kuat untuk mengevaluasi pasar berdasarkan variabel dasar akuntansi (nilai buku dan laba), dan jenis informasi lainnya yang mungkin relevan dalam memprediksi nilai perusahaan.

Namun demikian, model Ohlson merupakan model sederhana. Model Ohlson ini mengasumsikan bahwa investor bersifat netral terhadap risiko, akuntansi tidak bias, mempunyai clean surplus, tidak adanya peran detail dalam akuntansi, tidak ada informasi asimetri, tarif pajak yang dihadapi oleh pemegang saham tidak relevan, pilihan nyata tidak secara eksplisit diperhitungkan, laba abnormal dan " $v$ " berevolusi secara autoregressive (Ferraro dan Veltri dalam Heesameilita, 2012).

Dalam Model Ohlson (1995), nilai perusahaan dinyatakan dalam harga saham, dapat dilihat dari persamaan berikut Persamaan diatas menunjukkan bahwa nilai perusahaan ( NPt) pada waktu $t$ dipengaruhi oleh nilai buku ekuitas ( NBt), laba perusahaan ( LA1) dan informasi lain ( VLt ) yang masing-masing dikalikan dengan sebuah konstanta (a1 dan a2). Dengan demikian dapat diturunkan fungsi nilai perusahaan adalah sebagai berikut:

$$
\mathrm{NPt}=\mathrm{NBt}+\mathrm{a} 1 \mathrm{LA} 1+a 2 \mathrm{VLt}
$$

Model valuasi Ohlson (1995), mengejutkan karena diturunkan secara sederhana, namun berhasil menghilangkan keharusan memprediksi dividen dalam menghitung nilai perusahaan dengan hasil valuasi yang justru identik dengan nilai sekarang seluruh dividen ekspektasian.

\section{Nilai Perusahaan}

Nilai perusahaan dalam penelitian ini adalah harga pasar saham. Karena harga saham perusahaan menunjukkan nilai keseluruhan hasil reaksi dipasar modal oleh investor dalam menggambarkan kondisi suatu perusahaan. Nilai perusahaan menggunakan harga pasar saham dibanding nilai buku saham dikarenakan nilai buku ekuitas tidak menjelaskan modal intelektual yang dimiliki perusahaan (Kujunasivu \& Lonnqvist dalam Heesameilita, 2012).

\section{Nilai Buku Ekuitas}

Nilai buku ekuitas menggambarkan jumlah ekuitas pemegang saham yang dilaporkan dan dikurangi oleh saham preferen dan dilaporkan dalam laporan posisi keuangan perusahaan. Nilai buku ekuitas juga merupakan nilai aset bersih yang dimiliki oleh perusahaan yaitu selisih dari total aset dikurang liabilitas yang dimiliki perusahaan. Nilai buku ekuitas menggambarkan 
informasi mengenai besarnya nilai sumberdaya perusahaan dalam satuan moneter. (Fadliyah,2008)

\section{Laba Per Saham}

Penelitian ini menggunakan informasi laba per saham dasar sebagai variabel penelitian. Menurut PSAK 56 revisi (2010) "Laba per Saham", laba per saham dasar dihitung dengan membagi laba atau rugi yang dapat diatribusikan kepada pemegang saham biasa entitas induk (pembilang) dengan jumlah rata-rata tertimbang saham biasa yang beredar (penyebut) dalam suatu periode. Tujuan informasi laba per saham dasar adalah menyediakan ukuran mengenai hak setiap saham biasa entitas induk atas kinerja entitas selama periode pelaporan.

Review Penelitian Terdahulu, Fadhilyah (2008) sebelumnya telah mereplikasi penelitian yang dilakukan oleh Collins, et al (1999) mengenai relevansi nilai perusahaan yang diukur dengan memperhitungkan pengaruh nilai laba positif dan laba negatif dalam hubungan variabel independen dan dependen. Hasil penelitian tersebut mengungkapkan bahwa nilai buku ekuitas dan laba per saham memiliki pengaruh signifikan terhadap harga saham. Perbedaan pengaruh variabel laba per saham dan nilai buku ekuitas terhadap harga saham pada masing-masing sampel perusahan terletak pada besaran koefisien dan arah hubungan. Analisis tersebut menyimpulkan bahwa dari seluruh sampel, hanya sampel perusahaan industri yang bersifat sicklikal yang terbukti dan sesuai dengan penelitian yang dilakukan oleh Collins, et al (1999).

Penelitian yang dilakukan oleh Heesameilita (2012) menggunakan tambahan variabel informasi modal intelektual yang diukur dengan menggunakan pengukuran VAIC dalam memenuhi variabel "informasi lain" pada model valuasi Ohlson (1995). Berdasarkan hasil penelitian ini, informasi nilai buku, laba per saham, efisiensi modal intelektual, dan efisiensi modal finansial dan fisik mempengaruhi nilai harga saham perusahaan. Namun hanya komponen efisiensi modal sumber daya manusia sebagai proksi modal intelektual yang memiliki relevansi nilai.

Penelitian yang dilakukan oleh Chalmers et al (2011) mengungkapkan bahwa informasi akuntansi (nilai buku dan laba per saham) oleh perusahaan mampu menjelaskan lebih baik nilai perusahaan yang diwakilkan oleh nilai return saham setelah periode perubahan sistem akuntansi ASBE (Accounting System for Bussiness Enterprises) pada tahun 2001. Penelitian ini juga menemukan bahwa nilai buku pada perusahaan yang memiliki jenis saham ganda ( $A \& B-$ share firms) memiliki relevansi nilai lebih tinggi dibanding perusahaan yang memiliki saham tunggal pada masa setelah perubahan sistem akuntansi.

Adhani \& Subroto (2013) menguji komponen informasi akuntansi nilai buku ekuitas dan laba akuntansi terhadap harga saham perusahaan. Penelitian ini menambahkan variabel arus kas operasional sebagai variabel memperkuat pengaruh data akuntansi terhadapa nilai perusahan. Dalam penelitiannya, ditarik kesimpulan bahwa informasi akuntansi (laba dan nilai buku) memiliki relevansi nilai namun tidak untuk komponen arus kas operasional. Hasil penelitian ini juga mengungkapkan informasi laba memiliki relevansi nilai lebih tinggi dibanding informasi akuntansi lainnya.

Almilia \& Sulistyowati (2007) sebelumnya telah menggunakan variabel arus kas operasional dalam mengukur relevansi nilai informasi keuangan pada perusahaan manufaktur di Bursa Efek Jakarta. Penelitian ini dilakukan saat terjadinya masa krisis ekonomi Indonesia pada tahun 1995 hingga 2004. Hasil penelitian menggunakan uji regresi linier mengungkapkan bahwa secara parsial, nilai laba perusahaan dan arus kas operasi perusahaan memiliki pengaruh signifikan 
terhadap harga saham selama periode sebelum dan sesudah krisis ekonomi. Sedangkan variabel nilai buku ekuitas hanya mempengaruhi harga saham pada periode terjadinya krisis ekonomi.

Subekti (2010) meneliti tentang pengaruh struktur kepemilikan saham dan afiliasi grup bisnis terkait relevansi nilai informasi akuntansi. Penelitian ini menyimpulkan bahwa perusahaan yang berafiliasi dalam bentuk kelompok bisnis dan mempunyai banyak anak perusahaan mempunyai kualitas laporan keuangan yang lebih rendah jika dibandingkan dengan perusahaan yang beroperasi secara tunggal. Simpulan penelitian ini berikutnya adalah bahwa investor institusi mempunyai peranan yang sangat besar dalam mengontrol operasional perusahaan maupun implementasi tatakelola perusahaan yang baik.

Pengembangan Hipotesis; Relevansi nilai merupakan kemampuan informasi akuntansi dalam menjelaskan nilai perusahaan. Nilai perusahaan dapat tercermin dari harga pasar saham perusahaan tersebut. Dimana pada saat harga pasar saham tinggi berarti saham tersebut diminati oleh investor, dan meningkatnya permintaan saham akan menyebabkan nilai perusahaan akan semakin tinggi. Sebelum mengambil keputusan investasi atas suatu sekuritas, investor perlu melakukan analisis fundamental terhadap kinerja perusahaan melalui laporan keuangan perusahaan tersebut. Laba dan nilai buku ekuitas merupakan dua ukuran yang mengikhtisarkan laporan keuangan. Nilai buku ekuitas merupakan ukuran posisi keuangan sekaligus nilai aset bersih sebagai modal menghasilkan laba, sedangkan laba merupakan ukuran laba rugi yang mengikhtisarkan imbal hasil dari aset bersih yang telah digunakan. Kedua informasi ini merupakan informasi keuangan yang menjadi perhitungan investor dalam analisis fundamental. Adhani \& Subroto (2013); Heesameilita (2012); Kusumo \& Subekti (2013) menemukan bahwa nilai buku ekuitas dan nilai laba per saham memiliki pengaruh signifikan dalam pembentukan harga saham baik secara simultan maupun parsial. Hal ini berarti nilai buku ekuitas dan laba perusahaan memiliki relevansi nilai bagi investor. Berdasarkan penjelasan diatas maka hipotesis dalam penelitian ini adalah:

H1 : Nilai buku ekuitas per saham memiliki relevansi nilai

H2 : Laba per saham memiliki relevansi nilai

H3 : Nilai buku ekuitas per lembar saham dan laba per saham memilikl relevansi nilai

Kondisi perusahaan yang menghasilkan laba/rugi negatif akan mempengaruhi keputusan investor yang dapat tercermin dari turunnya harga saham. Hal ini diakibatkan penurunan laba merupakan salah satu bentuk informasi yang bersifat bad news bagi investor. Kondisi perusahaan yang menghasilkan laba secara kontinyu dan konsisten akan membuat persepsi investor kepada perusahaan menjadi baik. Hal ini akan membuat relevansi nilai yang tercermin dalam nilai buku ekuitas dan laba per saham perusahaan pada perusahaan kondisi laba/rugi positif dapat lebih tinggi dibanding pada kondisi perusahaan yang memiliki laba negatif. Berdasarkan penjelasan diatas maka hipotesis selanjutnya dalam penelitian ini adalah:

H4 : Relevansi nilai buku ekuitas per saham pada kondisi perusahaan laba/rugi positif lebih tinggi dibanding perusahaan pada kondisi laba/rugi negative

H5 : Relevansi nilai laba per saham pada kondisi perusahaan laba/rugi positif lebih tinggi dibanding perusahaan pada kondisi laba/rugi negatif 


\section{METODOLOGI PENELITIAN}

Variabel Penelitian ini menggunakan empat jenis variabel untuk menghasilkan model regresi dalam mengukur relevansi nilai informasi akuntansi perusahaan. Variabel-variabel yang digunakan dalam penelitian ini antara lain: 1) Variabel terikat (Dependent Variable). Alam penelitian ini yang menjadi variabel terikat adalah nilai perusahaan yang diproksikan dengan Harga Pasar Saham ( $\mathrm{Pt}$ ) pada tanggal 1 April. 2) Variabel bebas (Independent Variable), Nilai buku ekuitas per lembar saham menunjukkan nilai dari setiap saham atas total aset bersih yang dimiliki perusahaan.Nilai BVPS dapat dihitung dengan formula:

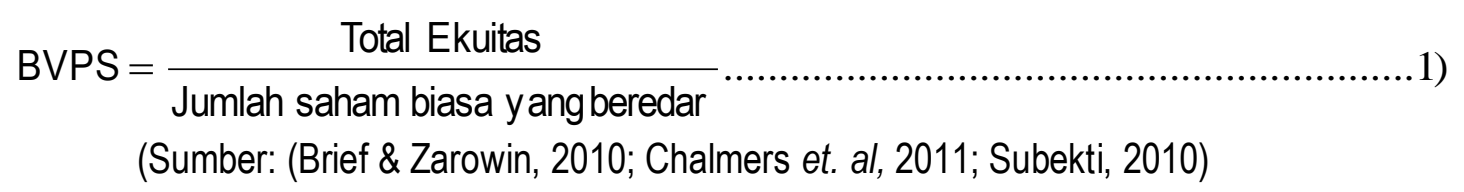

Laba per saham adalah pendapatan bersih perusahaan selama setahun dibagi dengan jumlah rata-rata lembar saham yang beredar. Pendapatan bersih tersebut dikurangi dengan porsi saham preferen dan laba kepentingan minoritas yang diperhitungkan untuk tahun tersebut.. Laba per saham dapat dihitung dengan formula sebagai berikut:

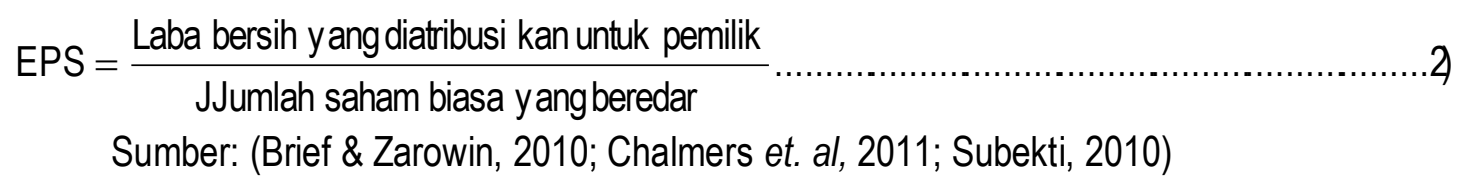

Variabel Moderasi (Moderating Variable), Dalam penelitian ini variabel yang diduga memoderasi hubungan antara variabel independen dan dependen adalah kondisi laba/rugi perusahaan. Kondisi laba/rugi perusahaan menggambarkan kondisi laba/rugi tahun $t$ dibanding tahun (t-1), perusahaan dikatakan memiliki laba/rugi negatif bilai laba tahun $t$ lebih kecil dibanding tahun (t-1). Variabel ini merupakan variabel yang digunakan untuk mengukur relevansi nilai pada dua kelompok subsampel. Dalam penelitian ini, kelompok tersebut adalah kelompok perusahaan yang menghasilkan laba/rugi positif dan perusahaan yang menghasilkan laba/rugi negatif. Untuk perusahaan yang dalam kondisi laba/rugi positif diberi nilai "1" dan untuk perusahaan yang dalam kondisi laba/rugi negatif diberi nilai "0".

Variabel Kontrol (Control Variable), Dalam penelitian ini variabel kontrol yang digunakan adalah ukuran perusahaan, struktur kepemilikan saham dam afiliasi grup bisnis. Afiliasi grup bisnis menggambarkan struktur perusahaan. Perusahaan yang berafiliasi berarti perusahaan tersebut memiliki anak perusahaan dalam menjalankan operasinya. Sedangkan perusahaan yang tidak berafiliasi merupakan perusahaan tunggal. Subekti (2010) melakukan penelitian mengenai relevansi nilai terhadap kelompok perusahaan berafiliasi dan tunggal. Hasil penelitian ini mengungkapkan bahwa perusahaan berafiliasi memiliki relevansi nilai lebih rendah dibanding perusahaan.

Struktur kepemilikan saham merupakan porsi kepemilikan saham dalam suatu perusahaan yang dinyatakan dalam persen. Subekti (2010) melakukan penelitian relevansi nilai terhadap kelompok kepemilikan saham besar dan kecil. Hasil penelitian tersebut mengungkapkan bahwa terjadi perbedaan relevansi nilai antara kepemilikan saham besar dan kecil. Hal ini mengungkapkan bahwa dikotomi kepemilikan saham akan memberikan pengaruh terhadap model regresi. Untuk itu dalam penelitian ini, pengaruh tersebut dinetralisir dengan cara 
menjadikan variabel struktur kepemilikan saham menjadi variabel pengendali dalam model yang akan diuji. Pengukuran variabel ini menggunakan variabel dummy karena variabel ini bersifat kualitatif. Dalam penelitian ini, bagi perusahaan yang memiliki kepemilikan saham diatas median akan diberi nilai "1" dan bagi perusahaan yang tidak memiliki kepemilikan saham diatas median diberi nilai "0".

Ukuran perusahaan adalah suatu skala atau nilai dimana perusahaan dapat diklasifikasikan besar kecilnya berdasarkan total aktiva, total penjualan, kapitalisasi pasar, dan lain sebagainya. Ukuran perusahaan merupakan simbol yang berhubungan dengan peluang dan kemampuan perusahaan untuk masuk ke pasar modal dan jenis pembiayaan lainnya yang menunjukkan kemampuan meminjam. Pada penelitian ini, proksi dari ukuran perusahaan adalah menggunakan nilai dari logaritma natural total penjualan. Hal ini dikarenakan populasi penelitian berupa perusahaan manufaktur dimana kegiatan operasional utama perusahaanperusahaan tersebut adalah melakukan penjualan.

Teknik Penentuan Populasi dan Sampel; Populasi dalam penelitian ini adalah seluruh perusahaan manufaktur yang terdaftar di Bursa Efek Indonesia. Teknik sampling yang digunakan adalah teknik purposive sampling. Adapun kriteria sampel yang ditentukan dalam penelitian ini adalah: 1) Perusahaan yang mempublikasikan data laporan keuangan pada tahun periode penelitian, 2) Perusahaan memiliki akhir tahun fiskal yang berakhir bulan Desember, 3) Perusahaan memiliki ekuitas bernilai positif, 4) Perusahaan menyajikan laporan keuangan dalam mata uang Rupiah, 5) Tersedianya data-data yang diperlukan mengenai harga saham, nilai buku ekuitas dan laba perusahaan.

Model Penelitian; Untuk menguji hipotesis yang telah dirancang, maka perlu dibentuk model regresi linier berganda, Model ini digunakan untuk melihat besarnya pengaruh variabel independen terhadap variabel dependen. Persamaan regresi yang digunakan dalam penelitin ini adalah:

Menguji hipotesis 1, 2 dan 3 digunakan Model I yaitu:

$P i, t+3=a_{0}+\beta 1 B V P S i, t+\beta 2 E P S i, t+\beta 3$ GROUPi, $t+\beta 4$ SHAREi,t $+\beta 5$ LnSIZEi,t $+\varepsilon i, t$

Model I digunakan untuk menguji apakah nilai buku ekuitas per saham dan laba per saham memiliki relevansi nilai terhadap harga perusahaan.

Menguji hipotesis 4 dan 5 digunakan Model II yaitu:

$$
P i, t+3=a_{0}+\beta 1 B V P S i, t+\beta 2 E P S i, t+\beta 3 D N l i, t+\beta 4 D N l i, t^{*} B V P S \text { it }+\beta 5 D N l i, t \text { *EPS I,t + }
$$
$\beta 6$ GROUPi,t $+\beta 7$ SHARE i,t $+\beta 8$ LnSIZEi, $t+\varepsilon i, t$

Model II digunakan untuk mengelompokkan perusahaan berdasarkan kondisi laba perusahaan. Model ini juga digunakan untuk menguji apakah relevansi nilai yang terjadi pada perusahaan kondisi laba positif lebih tinggi dibanding perusahaan kondisi negative, Keterangan untuk model I dan II dapat dijelaskan sebagai berikut:

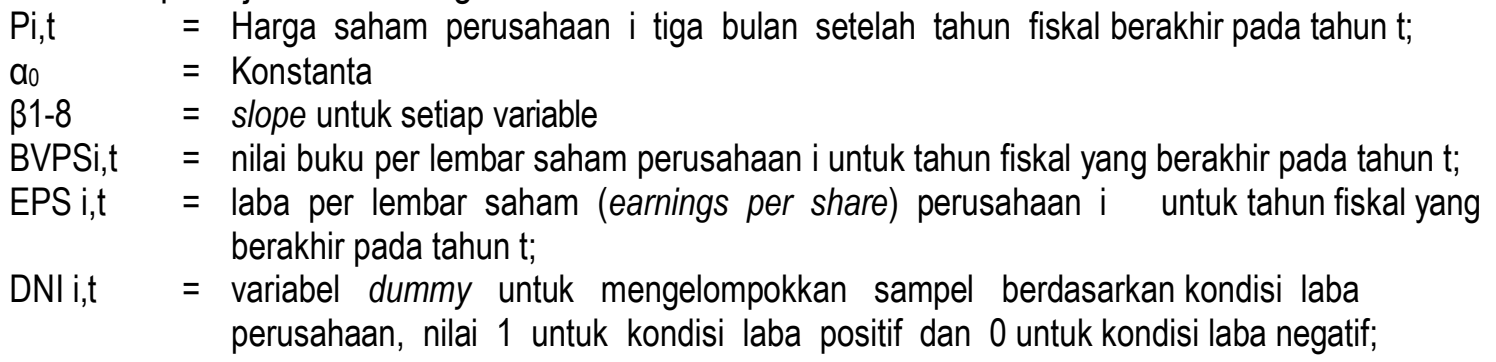




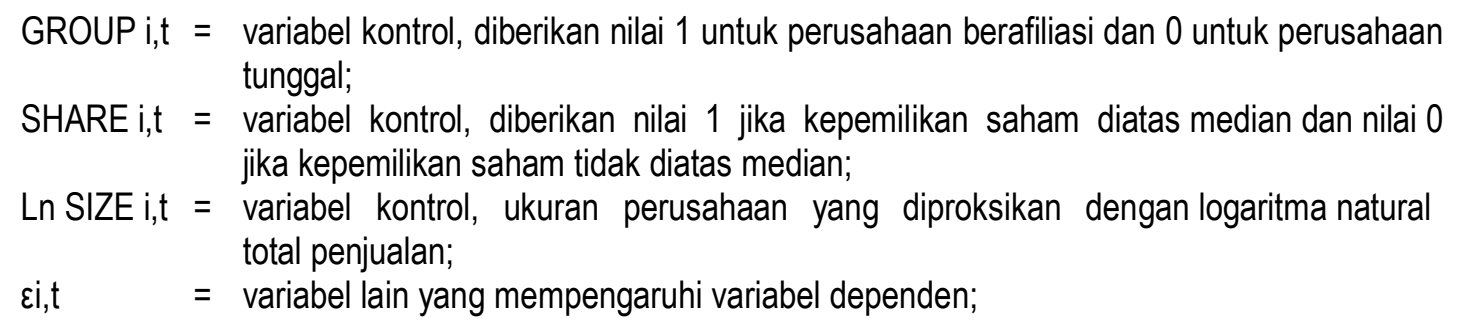

\section{HASIL DAN PEMBAHASAN}

\section{Pengujian Pencilan (Outlier)}

Pengujian pencilan dalam penelitian ini menggunakan teknik pengahapusan data outlier menurut Seo (2002) yaitu dengan menggunakan nilai Z-Score. Variabel utama dalam penelitian ini yaitu Pt, BVPS dan EPS ditransformasikan terlebih dahulu kedalam nilai Z-Score. Jika nilai ZScore diatas nilai 3 absolut, maka dikategorikan sebagai data outlier. Pada sampel penelitian ini digunakan 3 kali pengujian Z-Score dikarenakan pada pengujian pertama dan kedua masih terdapat outlier yang ekstrim. Setelah melalui pengujian pencilan, terdapat 26 data yang outlier sehingga dikeluarkan dalam penelitian ini. Dengan demikian maka sampel yang digunakan dalam penelitian ini berjumlah 163 laporan keuangan perusahaan manufaktur.

\section{Statistik Deskriptif}

Statistik deskriptif bertujuan untuk memberikan gambaran atau deskripsi dari sekumpulan data yang dilihat dari jumlah sampel, nilai minimum, nilai maksimum, nilai rata-rata dan standar deviasi dari masing-masing variabel. Dalam penelitian ini statistik deskriptifnya adalah sebagai berikut:

Tabel. 4.1 Statistik Deskriptif

\begin{tabular}{|c|c|c|c|c|c|}
\hline & $\mathrm{N}$ & Minimum & Maximum & Mean & Std. Deviation \\
\hline $\mathrm{Pt}$ & 163 & 5,00 & 14675,00 & 1410,80 & 2287,29003 \\
\hline BVPS & 163 & 10,65 & 5883,57 & 770,62 & 935,09195 \\
\hline EPS & 163 & $-359,00$ & 796,00 & 61,04 & 131,73773 \\
\hline LnSIZE & 163 & 20,74 & 32,90 & 27,72 & 1,82974 \\
\hline Valid N & 163 & & & & \\
\hline
\end{tabular}

Tabel 4.1 menjelaskan tentang deskripsi sampel dalam penelitian ini. Berdasarkan hasil pengolahan data dapat dilihat bahwa harga saham terendah dalam penelitian ini adalah sebesar Rp. 5,00 (SIPD-2013) dan nilai saham tertinggi adalah sebesar Rp. 14675,00 (ICBP2014). Rata-rata harga saham adalah sebesar Rp. 1.410,00 dengan standar deviasi sebesar Rp. 2287,29. Nilai buku per saham (BVPS) memiliki nilai terendah sebesar Rp. 10,65/lembar saham (AKKU-2013) dan nilai maksimum sebesar Rp. 5883,57/lembar saham (TCID2013). Rata-rata nilai buku per saham adalah sebesar Rp. $770,62 / l e m b a r$ saham. Nilailaba per saham (EPS) memiliki nilai terendah Rp. -359,00/lembar saham (MLIA-2013) dan nilai tertinggi sebesar Rp. 796,00/lembar saham (TCID-2013). Rata- rata nilai laba per saham adalah sebesar Rp. 27,72/lembar saham. Variabel ukuran perusahaan memiliki nilai terendah yaitu sebesar 20,74 dan nilai tertinggi 32,90. Nilai ini merupakan nilai logaritma natural dari nilai penjualan perusahaan. Rata- rata nilai ukuran perusahaan dalam penelitian ini adalah sebesar 
27,72. Pada periode 2013-2014, perusahaan manufaktur di Indonesia terdiri dari 113 perusahaan yang berafiliasi dan 50 perusahaan tunggal. Sedangkan dari sisi struktur modal perusahaan, sebanyak 47,2\% (77 perusahaan) dari total sampel memiliki kepemilikan saham yang dipegang oleh suatu pihak diatas $50 \%$. Sedangkan sisanya yaitu 86 perusahaan memiliki kepemilikan yang tidak diatas $50 \%$ atau kepemilikan saham cenderung tidak dominan. Selama periode penelitian terdapat 76 perusahaan yang mengalami kondisi laba/rugi positif. Sedangkan sebanyak 87 perusahaan mengalami kondisi laba/rugi negatif.

Pada pengujian asumsi klasik untuk kedua model, didapatkan bahwa kedua model mengalami masalah heteroskedastisitas dan normalitas. Untuk itu model penelitian ditransformasikan dengan cara mengubah bentuk variabel y menjadi bentuk logaritma natural.

\section{Pengujian Hipotesis}

\section{Hipotesis satu $\left(\mathrm{H}_{1}\right)$ : Nilai buku ekuitas per saham memiliki relevansi nilai}

Hipotesis diterima. Dimana variabel BVPS memiliki pengaruh positif dan signifikan terhadap variabel Pt. Hal ini berarti nilai buku ekuitas per saham memiliki relevansi nilai dan nilai buku ekuitas per saham dapat digunakan oleh investor dalam melakukan analisis fundamental karena memiliki informasi yang relevan dengan harga saham. Hasil ini juga menguatkan pendapat bahwa perusahaan dengan nilai ekuitas tinggi mampu menarik perhatian investor agar membeli saham perusahaan. Koefisien positif yang dihasilkan dalam pengujian membuktikan bahwa investor lebih meminati perusahaan dengan nilai ekuitas yang lebih tinggi dan menjadi informasi dasar dalam pengambilan keputusan investasi. Hal ini sejalan dengan penelitian yang dilakukan oleh Adhani \& Subroto (2013); Cahyowati \& Ratmono (2012); Chalmers, et.al (2011); Fadhliyah (2008); Kusumo \& Subekti (2013); Subekti (2010) dan Heesameilita (2012). Oleh karena itu dapat dikatakan bahwa nilai buku ekuitas per saham memiliki relevansi nilai.

\section{Hipotesis dua $\left(\mathrm{H}_{2}\right)$ Laba Per Saham memiliki relevansi nilai}

Hipotesis diterima. Dimana laba per lembar saham memiliki pengaruh positif dan signifikan terhadap nilai perusahaan. Ini berarti laba per lembar saham memiliki relevansi nilai. Tanda positif pada nilai koefisien tersebut menunjukkan bahwa laba per lembar saham (EPS) memiliki hubungan yang positif dengan harga saham perusahaan $(P)$. Investor dapat menggunakan informasi laba per lembar saham dalam menilai perusahaan. Laba yang tinggi merupakan ekspektasi umum bagi para investor. Dari hasil pengujian ini, maka dapat dikatakan bahwa investor akan lebih meminati saham yang memiliki laba per saham tinggi dibanding saham yang memiliki laba per saham rendah. Banyaknya permintaan investor akan saham dengan laba tinggi akan membuat harga saham perusahaan naik. Sebaliknya, laba per saham yang rendah cenderung membuat harga saham tersebut menjadi turun.

Hasil penelitian ini sejalan dengan Adhani \& Subroto (2013); Almilia \& Sulistyowati (2007); Cahyowati \& Ratmono (2012); Fadhliyah (2008); Kusumo \& Subekti (2013); Subekti (2010) dan Heesameilita (2012). Oleh karena itu dapat dikatakan bahwa nilai laba per saham per saham memiliki relevansi nilai. 


\section{Hipotesis tiga $\left(\mathrm{H}_{3}\right)$ : Nilai buku ekuitas per lembar saham dan laba per saham memiliki relevansi nilai}

Hipotesis diterima. Pada tabel 4.2 dapat dilihat bahwa nilai sig. F-statistics lebih kecil dari 0,05 . Hasil uji $F$ ini memberikan kesimpulan bahwa variabel nilai buku ekuitas per saham dan nila laba per saham secara bersama- sama memiliki pengaruh yang signifikan terhadap harga pasar saham. Dengan demikian, dapat disimpulkan bahwa Model Valuasi Ohlson (1995) terbukti secara empiris berdasarkan hasil penelitian ini. Hasil penelitian ini sesuai dengan penelitian yang dilakukan oleh Chalmers, et. al (2011), Cahyowati \& Ratmono (2012), dan Heesameilita (2012) dimana ke semua penelitian menunjukkan nilai signifikansi dari Uji-F adalah lebih kecil dari 0,05. Dengan demikian dapat disimpulkan bahwa nilai laba per saham dan nilai buku per saham secara bersama-sama memiliki relevansi nilai.

Tabel 4.2

Ringkasan Hasil Uji Regresi Model I

\begin{tabular}{|c|c|c|c|c|c|}
\hline $\begin{array}{l}\text { Variabel } \\
\text { Dependen }\end{array}$ & $\begin{array}{c}\text { Variabel } \\
\text { Independen }\end{array}$ & Koefisien & t-statistik & Sig. & Estimasi \\
\hline \multirow{10}{*}{ LnPt } & C & $-1,053$ &,- 914 & 0,362 & \\
\hline & BVPS & 0,000 & 2,099 & $0,037^{*}$ & H1 : + \\
\hline & EPS & 0,004 & 4,989 & $0,000^{* \star}$ & $\mathrm{H} 2:+$ \\
\hline & GROUP & 0,351 & 2,194 & $0,030^{*}$ & \\
\hline & SHARE & 0,407 & 2,787 & $0,006^{* *}$ & \\
\hline & LnSIZE & 0,235 & 5,461 & $0,000^{* *}$ & \\
\hline & R-square & & & & 0,588 \\
\hline & Adjusted R-square & & & & 0,575 \\
\hline & F-statistic & & & & 44,885 \\
\hline & Sig. F-statistic & & & & $0,00000^{* \star}$ \\
\hline
\end{tabular}

Sumber: data diolah (2016)

Hipotesis empat $(\mathbf{H} 4)$ "Relevansi nilai buku ekuitas per saham pada kondisi perusahaan laba/rugi positif lebih tinggi dibanding perusahaan pada kondisi laba/rugi negatif". Hipotesis ditolak. Interaksi antara kondisi laba perusahaan dengan nilai buku ekuitas per saham memiliki hubungan negatif dan signifikan. Hal ini membuat nilai koefisien dari variabel nilai buku ekuitas per saham menurun sehingga dapat disimpulkan dengan kondisi laba perusahaan yang positif akan membuat relevansi nilai buku ekuitas per saham menjadi lebih rendah dengan berkurangnya nilai koefisien dari variabel BVPS.

Dapat disimpulkan bahwa pada kondisi perusahaan saat sedang mengalami kondisi laba negatif, maka relevansi nilai yang terjadi antara nilai buku ekuitas per saham terhadap harga saham lebih tinggi dibandingkan pada perusahaan dengan kondisi laba positif. Hal ini merupakan sebuah anomali dikarenakan seharusnya investor akan memberikan reaksi positif terhadap suatu keputusan investasi pada perusahaan yang dapat mempertahankan pertumbuhan laba. Hal ini dapat dikarenakan kondisi pasar modal Indonesia yang belum sepenuhnya efisien dan juga dapat dikarenakan penurunan laba yang terjadi sepanjang periode tidak terlalu signifikan sehingga tidak terlalu mempengaruhi keputusan investor. Informasi laba turun juga dapat "tertutupi" informasi positif lainnya semisalnya nilai penjualan yang meningkat atau penurunan hutang perusahaan. Hasil pengujian ini mengindikasikan masih ada variabel lain 
yang memoderasi hubungan antara variabel independen nilai buku per saham dengan variabel dependen harga saham.

Hipotesis lima $\left(\mathbf{H}_{5}\right)$ "Relevansi nilai laba per saham pada kondisi perusahaan laba/rugi positif lebih tinggi dibanding perusahaan pada kondisi laba/rugi negatif", Hipotesis diterima. Interaksi antara kondisi laba perusahaan dengan nilai laba per saham memiliki hubungan positif dan signifikan. Hal ini membuat nilai koefisien dari variabel laba per saham meningkat sehingga dapat disimpulkan dengan kondisi laba perusahaan yang positif akan membuat relevansi nilai laba per saham menjadi lebih tinggi dengan bertambahnya nilai koefisien dari variabel EPS karena interaksi variabel DNI dan EPS. Dapat disimpulkan bahwa kondisi laba yang mengalami pertumbuhan positif dapat memperkuat hubungan relevansi nilai laba per saham terhadap harga saham. Dengan adanya informasi laba positif maka investor akan memberikan reaksi positif terhadap keputusan investasi. Perusahaan yang mampu mempertahankan laba perusahaan terus meningkat setiap periodenya akan membuat kualitas laba meningkat di mata investor. Informasi pertumbuhan laba yang diterima investor akan membuat persepsi investor akan penggunaan laba sebagai indikator analisis fundamental menjadi lebih kuat. Sehingga penilaian laba perusahaan menjadi informasi penting dalam pengambilan keputusan investasi.

Tabel. 4.3

Ringkasan Hasil Uji Regresi Model II

\begin{tabular}{|c|c|c|c|c|c|}
\hline $\begin{array}{c}\text { Variabel } \\
\text { Dependen }\end{array}$ & $\begin{array}{l}\text { Variabel } \\
\text { Independen }\end{array}$ & Koefisien & t-statistik & Sig. & Estimasi \\
\hline \multirow{13}{*}{ LnPt } & C & $-0,921$ &,- 796 & 0,428 & \\
\hline & BVPS & 0,000 & 3,182 & $0,002^{* *}$ & \\
\hline & EPS & 0,002 & 2,293 & $0,023^{*}$ & \\
\hline & GROUP & 0,356 & 2,229 & $0,027^{*}$ & \\
\hline & $\overline{\text { SHARE }}$ & 0,407 & 2,783 & $0,006^{\star *}$ & \\
\hline & LnSIZE & 0,225 & 5,242 & $0,000^{* *}$ & \\
\hline & DNI & 0,222 & 1,194 & 0,234 & \\
\hline & DNI*BVPS & $-0,001$ & $-2,463$ & $0,015^{*}$ & $\mathrm{H} 4:+$ \\
\hline & DNIEPS & 0,004 & 2,367 & $0,019^{*}$ & $\mathrm{H} 5:+$ \\
\hline & R-square & & & & 0,606 \\
\hline & Adjusted R Square & & & & 0,585 \\
\hline & F-statistic & & & & 29,593 \\
\hline & Sig. F-statistic & & & & $0,00000^{* *}$ \\
\hline
\end{tabular}

sumber: data olahan (2016

Variabel Kontrol, Struktur Kepemilikan Saham, Hasil pengujian pada Model I menunjukkan bahwa variabel struktur kepemilikan saham memiliki pengaruh positif dan signifikan terhadap harga saham. Hal ini mendukung penelitian yang dilakukan oleh Subekti (2010) dimana hasil penelitian tersebut mengungkapkan pada perusahaan dengan kepemilikan saham besar memiliki relevansi nilai lebih tinggi dibanding perusahaan dengan kepemilikan saham kecil. Nilai koefisien variabel ini pada Model I adalah sebesar 0,407726 . Hal ini berarti bahwa setiap perusahaan yang memiliki kepemilikan saham diatas $50 \%$ oleh pihak tunggal 
maka harga pasar saham akan meningkat sebesar 0,407726 (dalam satuan In) atau jika dikonversi sekitar Rp. 1,50. Kondisiini dapat disebabkan oleh adanya kemampuan yang baik dari pemegang saham institusi dalam hal mengawasi kinerja setiap manajer untuk melakukan tindakan yang dapat merugikan pihak minoritas. Tata kelola yang baik dapat menyebabkan meningkatnya kualitas laporan keuangan yang dapat mempengaruhi nilai perusahaan di pasar modal dan respon investor.

Afiliasi Grup Bisnis, Hasil pengujian dalam penelitian ini menunjukkan bahwa perusahaan yang berafiliasi memiliki pengaruh signifikan positif terhadap harga saham. Hasil penelitian ini tidak dapat mendukung penelitian yang dilakukan oleh Subekti, (2010) dimana dalam penelitian tersebut perusahaan tunggal memiliki relevansi nilai yang lebih tinggi dibanding perusahaan yang berafiliasi. Hal ini dikarenakan penelitian ini mengikutsertakan variabel grup bisnis dalam model penelitian dan mengukur secara numerik seberapa besar pengaruh afiliasi grup bisnis terhadap relevansi nilai. Hasilnya adalah untuk perusahaan yang berafiliasi maka harga saham akan meningkat sebesar 0,35154 (dalam satuan In) atau setara dengan Rp.1,42. Hal ini dapat disebabkan karena perusahaan yang memiliki anak perusahaan cenderung merupakan perusahaan besar. Hal ini dapat dilihat dari rata-rata ukuran perusahaan afiliasi grup senilai Rp. 9.199.390.257.851 jauh lebih besar dibanding dengan perusahaan tunggal yakni sebesar Rp. 1.144.978.470.767. Selain itu dari nilai laba, perusahaan berafiliasi juga memiliki jumlah nilai yang lebih tinggi dibandingkan perusahaan tunggal. Nilai laba per saham perusahaan berafiliasi adalah senilai Rp. 468,53 per saham lebih besar dibanding laba per saham perusahaan tunggal sebesar Rp. 341,22. Ukuran perusahaan dan laba merupakan salah satu informasi fundamental utama yang akan dilihat investor dalam menentukan keputusan investasi. Unggulnya informasi keuangan perusahaan berafiliasi membuat investor lebih tertarik berinvestasi diperusahaan berafiliasi. Banyaknya permintaan akan membuat harga saham perusahaan naik.

Ukuran Perusahaan; Hasil pengujian ini menunjukkan bahwa ukuran peursahaan yang diwakilkan oleh nilai penjualan memiliki pengaruh positif dan signifikan terhadap harga saham. Hal ini merupakan suatu hasil yang wajar dikarenakan variable ukuran perusahaan adalah variabel fundamental yang efeknya harus dihilangkan dengan cara dilibatkan dalam model penelitian agar mereduksi bias hasil penelitian. Variabel ini terbukti positif signifikan dalam mempengaruhi nilai perusahaan. Hasil ini sesuai dengan penelitian yang dilakukan oleh Heesameilita, (2012) dimana ukuran perusahaan memiliki relevansi nilai terhadap harga saham.

\section{Kesimpulan}

Penelitian ini bertujuan untuk menemukan bukti empiris terkait relevansi nilai yang terjadi di perusahaan manufaktur yang terdaftar di Bursa Efek Indonesia pada periode 2013-2014. Dari hasil pengujian empiris didapatkan kesimpulan sebagai berikut:

1) Nilai buku ekuitas per saham terbukti memiliki relevansi nilai terhadap nilai perusahaan.

2) Nilai laba per saham terbukti memiliki relevansi nilai terhadap nilai perusahaan.

3) Nilai buku ekuitas per saham dan nilai laba per saham secara bersama- sama terbukti memiliki relevansi nilai terhadap nilai perusahaan.

4) Kondisi laba perusahaan mempengaruhi relevansi nilai buku ekuitas per saham yang terjadi. Pada kondisi laba, maka relevansi nilai yang terjadi antara nilai buku ekuitas per saham dan harga pasar saham menjadi lebih rendah.

5) Kondisi laba perusahaan mempengaruhi relevansi nilai laba per saham yang terjadi. Pada kondisi laba, maka relevansi nilai yang terjadi antara nilai laba per saham dan harga pasar saham menjadi lebih tinggi. 


\section{DAFTAR PUSTAKA}

Adhani, Yunita Sari dan Bambang Subroto (2013), Relevansi Nilai Informasi Akuntansi. Malang: Universitas Brawijaya.

Almilia, Luciana Spica, dan Dwi Sulistyowati (2007), Analisa Terhadap Relevansi Nilai Laba, Arus Kas Operasi dan Nilai Buku Ekuitas pada Periode disekitar Krisis Keuangan pada Perusahaan Manufaktur di BEJ. Inovasi dalam Menghadapi Perubahan Lingkungan Bisnis. Jakarta: Proceeding Seminar Nasional Universitas Trisakti. 1-17.

American Association of Individual Investors (2016), Earning Estimates and Their Impact on Stock Prices. Brief, Richard, dan Paul Zarowin (2010), The Value Relevance of Dividends, Book Value and Earnings. New York: New York University.

Cahyonowati, Nur, dan Dwi Ratmono (2012), Adopsi IFRS dan Relevansi Nilai Informasi Akuntansi. Jurnal Akuntansi dan Keuangan Vol. 14 No. 2: 105-115.

Chalmers, Keryn, Farshid Navissi, dan Wen Qu, 2011. Value Relevance of Accounting Information in China pre- and post-2001 Accounting Reform. Managerial Auditing Journal (Emerald Group Publishing Limited) Vol 25 no.8: 792-813.Dewan Standar Akuntansi

Keuangan (2010), Pernyataan Standar Akuntansi No. 56 Laba Per Saham. Jakarta: Ikatan Akuntan Indonesia.

Dwimulyani, Susi (2010), Relevansi Nilai Informasi Akuntansi Di Bursa Efek Indonesia. Jurnal Informasi, Perpajakan, Akuntansi dan Keuangan Publik Vol 5 No.2: 101-109.

Erwanda, Ade (2012), Pengaruh Profitabilitas, Resiko Finansial dan Keputusan Investasi Terhadap Nilai Perusahaan. Lampung: Universitas Lampung.

Fadhliyah, Alfi (2008), Analisis Pengaruh Nilai Buku Ekuitas dan Laba Per Saham Terhadap Harga Saham pada Perusahaan yang terdaftar di Bursa Efek Indoensia Periode 2002-2006. Depok: Universitas Indonesia.

Ghozali, Imam (2009), Ekonometrika. Semarang: Badan Penerbit Universitas Diponegoro

Gumanti, Tatang Ary, dan Elok Sri Utami (2002), Bentuk Pasar Efisien dan Pengujiannya. Jurnal Akuntansi \& Keuangan (Universitas Kristen Petra): 54-68.

Hand, John R. M (2005), the Value Relevance of Financial Statements in the Venture Capital Market. The Accounting Review Vol 4: 1-42.

Heesameilita, Anapratama, 2012. Relevansi Nilai Informasi Akuntansi (Nilai Buku Ekuitas dan Laba Akuntansi) dan Informasi Modal Intelektual: Studi Pada Perusahaan Terdaftar di Bursa Efek Indonesia. Depok: Universitas Indonesia.

Hutahean, Junius (2007), Pengaruh Modal Kerja dan Hubungannya Terhadap Profitabilitas Pada PTP. Nusantara I-X. Medan: Universitas Sumatra Utara.

Jogiyanto (2007), Metode Penelitian Bisnis. Yogyakarta: BPFE-YOGYAKARTA.

Keener, Mary Hilston (2003), The relative value relevance of earnings and bookvalue across industries." Journal of Finance and Accountancy: 1-19.

Kembuan, Prabowo Putra (2014), Perbandingan Pertumbuhan Laba dan Free Cash Flow Dalam Memprediksi Kinerja Harga Saham Perusahaan Manufaktur Yang Terdaftar Di Bursa Efek Indonesia. Makassar: Universitas Hasanuddin.

Kusumo, Yuro Bimo, dan Imam Subekti (2013), Relevansi Nilai Informasi Akuntansi, Sebelum Adopsi IFRS dan Setelah Adopsi IFRS Pada Perusahaan yang Tercatat Dalam Bursa Efek Indonesia. Malang: Universitas Brawijaya.

Lailia, Anni Mufida (2010), Relevansi Nilai Earnings dan Book Value terhadapKinerja Saham. Yogyakarta: Universitas Islam Sunan Kalijaga.

Martalena, dan Maya Malinda (2011), Pengantar Pasar Modal. Yogyakarta: Penerbit ANDI. 
Nurhasanah, Rahmalia (2013), Pengaruh Return on Assets, Return On Equity dan Earning Per Share Terhadap Harga Saham. Bandung: Universitas Widyatama.

Ohlson, James A. (1995), Earnings, Book Value, and Dividens in Equity Valuation." Contemporary Accounting Research Vol 11: 661.

Puspitaningtyas, Zarah (2012), Relevansi Nlai Informasi Akuntansi dan Manfaatnya Bagi Investor. Jurnal Ekonomi dan Keuangan: 164-174.

Rosari, Eva Christina (2014), Relevansi Laba Akuntansi dan Nilai Buku Terhadap Harga Saham dengan Moderasi Corporate Governance Pada Perusahaan Yang Terdaftar di BEI Tahun 2010-2012. Jurnal Akuntansi Mahasiswa Vol. 3 No.2: 1-21

Sangadji, Etta Mamang, dan Sopiah (2010), Metodologi Penenlitian. Yogyakarta: ANDI.

Scott, William R. (2007), Financial Accounting Theory 3rd ed. Toronto: Pearson Education Canada Inc.

Subekti, Imam (2010), Relevansi Nilai Informasi Akuntansi, Struktur Kepemilikan Saham dan Afiliasi Group Bisnis Pada Perusahaan Publik Indonesia. Malang: Universitas Brawijaya, 123.

Suliyanto (2009), Metode Riset Bisnis. Yogyakarta: Penerbit ANDI.

Sunariyah (2011), Pengantar Pengetahuan Pasar Modal. Yogyakarta: UPP STIM YKPN 